\title{
Charles M. In the Footsteps of the Prince: Rosenberg A Look at Renaissance Ferrara
}

The history of Ferrara and its princes has left a clear and readable imprint on the city's streets, palaces and churches. Written in their stones is the memory of what has gone before. Ferrara was the site of the Nexus 2000 conference on architecture and mathematics, 4-7 June 2000.

\section{Introduction}

As you approach Ferrara by train or car, traveling north from Bologna or south from Venice, you pass through vast fields of grain and vegetables, vineyards and fruit orchards. The landscape is remarkably flat but also richly productive and fertile. In the late spring you'll be treated to fields of anemones and blizzards of cherry, pear, and apple blossoms. In the summer, you'll see verdant vineyards and seas of crimson poppies and wildflowers lining the tracks and roadside. But if your visit to the city happens to be in the winter or very early spring and you arrive at twilight, you may see the landscape slowly dissolve before your eyes, as the countryside is gradually swallowed up in a dense, embracing fog. The journey to Ferrara takes you into the heartland of the broad flat alluvial plain of the Po river valley, the Val Padana. This snaking torrent, with its dozens of major and minor tributaries, saturates the soil from the rice fields of Lombardy to the farms of Emilia-Romagna, condemning the cities along its banks to winter nights of almost perpetual fog. Dense mists often invade Ferrara at nightfall and turn its streets in narrow dripping tunnels of darkness dotted with pools of light from glowing street lamps. It is during these months in particular that the city invites a sort of romantic reverie. Walking in the evening mist on the cobblestones of the magisterial Corso Ercole I d'Este or along the narrow Via Ragno, it's easy to imagine how this now thriving Emilian city might have appeared hundreds of years ago, devoid of cars and free of the smell of kerosene heaters. You can picture Ferrara at slumber, its gates closed until dawn, its streets and piazzas empty except for a passing watchman, the city waiting to awaken to a bustle of carts and oxen, the footsteps of peasants and artisans, and the hoof beats of aristocrats' horses. But one need not wait for these damp winter nights to indulge such a fantasy, for the history of Ferrara and its princes has left a clear and readable imprint on the city's streets, palaces and churches. Written on their stones is the memory of what has gone before. 


\section{Ferrara's earliest periods}

The origins of Ferrara are uncertain, but contemporary historians place them sometime in the early middle ages. ${ }^{1}$ The city's history has always been intimately involved with that of the Po. The river's periodic flooding and recession have deposited a deep layer of rich soil in the Val Padana, creating the agricultural wealth which is one of the major assets of Northern Italy. Furthermore, in pre-modern times, travel by water was one the quickest and most efficient ways of transporting merchandise and people over large distances. ${ }^{2}$ The Po, the longest river in Italy, with its numerous tributaries expanded by a vast network of man-made canals, formed a sort of superhighway traversing the peninsula from the marshy delta above Comacchio to Turin. In the sixth and seventh centuries, the primary channel of the river, which is considerably north of Ferrara today, brought it right by the site of the present day city. ${ }^{3}$ In fact, Ferrara was founded at a point where the river divided into two branches, the Po di Primaro and the Po di Volano. In the fifth and sixth centuries, this region was controlled by the Byzantine Exarchs of Ravenna, Byzantine episcopal rulers. But in the later sixth and early seventh century, as the Eastern Empire's grip on Italy weakened under pressures from both the Roman papacy in the south and tribal cultures in the north, military encampments and religious foundations were established along natural defensive barriers like the Po. These settlements served as regional spiritual, political and military outposts. Current thinking links the origins of Ferrara to one of these outposts. In the early seventh century a castrum, or Byzantine fortress, was probably constructed on the northern banks of the river and in fact, as Francesca Bocchi has been able to determine ${ }^{4}$, aerial photographs have revealed the outlines of this structure in the street patterns on the southeastern side of the city. Two concentric horseshoes formed by the via Cammello-Carmelino and Via Borgo di Sotto-Ghisglieri on the outside, and Via Belfiore-Fondo Banchetto on the inside, describe the outlines of the original walls of this Byzantine citadel. South of this military encampment on a point of land formed by the division of the Po, the first cathedral of the city, dedicated to St. George, was founded. The original site of this church, at the southeastern corner of modern Ferrara, is still marked by a large monastic complex which continues to bear the original dedication to St. George. Although it contains an impressive fifteenth-century tomb of Bishop Lorenzo Roverella, the present church is primarily a seventeenth- and eighteenth-century structure.

During the period between the eighth and the twelfth centuries, the city of Ferrara continued to grow, with the majority of the settlement taking place on the north bank of the Po. The remains of the ninth- and tenth-century circuit walls and settlements can be seen in the parallel undulating paths of the Via Garibaldi/Contrari/Zemola and Via della Concia/Borgoricco/ Mazzini/Sarceno and in the arrangement of thin rectangular blocks to the west of the Via Boccacanale di Santo Stefano, a street which marks the location of a medieval canal which connected the center of the city with the Po. One can gain a sense of the scale of the city in the high middle ages can be found along Ferrara's southern edge and the area of the Byzantine citadel. The narrow cobblestone streets, some scarcely wider than a footpath, give a real sense of what the city was like in the middle ages and early Renaissance. These include the Via Chiodaiuoli, street of the ironmongers, crossed by a file of slim, brick buttresses; the Via Ragno, lined by typical red-brick houses with protruding sporti; the dramatic Via Volte, 
bridged by a succession of enormous pointed vaults supporting the second and third stories of buildings which actually span the roadway; the still vibrant arcaded commercial Via Romano, as well as the more twisting paths in the district of the castrum.

\section{The city's center}

The center of Ferrara began to shift significantly in the twelfth century. Around 1130, in a move motivated by the congruence of a number of political factors associated with the rise of the city as an independent commune, Bishop Landolfo of Ferrara decided to construct a new cathedral at the northernmost limits of the city, actually outside of what had been the tenthcentury circuit of walls (Figure 1). This cathedral, which dates from around 1135 and which is also dedicated to Saint George, has undergone a number of changes in its long history. ${ }^{5}$ Its rosy marble façade, which has elements of both the Romanesque and Gothic styles, is unusual, for although the plan of the building is that of a typical basilican church with a high central nave flanked by lower side aisles, the façade doesn't acknowledge this. Instead, all three sections of the tripartite frontispiece are the same height, creating a decorative screen wall which is unmasked at the gable level where the sky is visible through the lobed oculi in its side peaks. The center of the building is dominated by the main doorway which is embraced by a protruding two-story pedimented porch in typical Romanesque ecclesiastical style. The porch is supported on columns, which in turn are borne on the shoulders of men seated on the backs

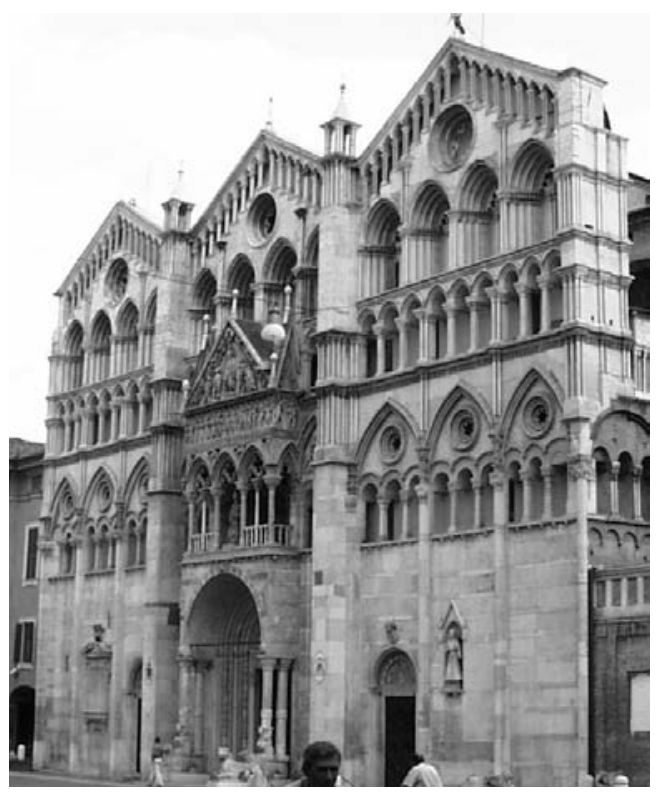

Fig. 1.

Façade, Cathedral of Saint George, Ferrara. (Photo K. Williams)

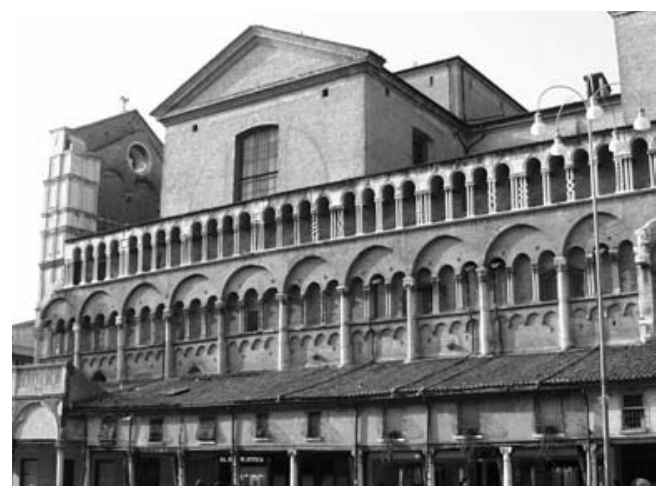

Fig. 2.

Southern flank of the Cathedral of St. George, Ferrara. (Photo K. Williams) 
of crouching lions. Over the main doorway is a lunette with an energetic relief depicting St. George and the Dragon. The second story of the porch is dominated by a colonnade which runs across the entire façade, creating the typical arcaded perforations of the Romanesque style. In the center of this arcade there was a fifteenth-century image of the Madonna and Child, known as the Madonna of the Pomegranate, done by the Sienese sculptor Jacopo della Quercia. The original statue is today in the cathedral museum. Above this, in the frontispiece frieze and pediment, is an image of the Last Judgement that continues on into pointed lunettes in the narrow bays flanking the porch. Although restored many times, the façade of the Cathedral still looks the way it would have throughout most of its history.

Unfortunately, the interior of the church has been significantly altered. Passing through its portals one enters a broad atrium, to the left of which a staircase leads to the cathedral museum. This museum houses, among other treasures, the original della Quercia Madonna, twelfthcentury reliefs from the destroyed Portal of the Months, Cosmé Tura's famous mid-fifteenthcentury organ shutters done in his typical bony, metallic, agitated style, with St. George and the Dragon on one side and the Annunciation on the other ${ }^{6}$, and the Cathedral's extraordinary collection of illuminated fifteenth- and sixteenth-century liturgical manuscripts. ${ }^{7}$ From the atrium one passes into the interior, where stucco decorations cover the piers and walls, transforming the building into an eighteenth-century structure. The nave ends in an apsidal choir, designed by the most famous Ferrarese architect of the Renaissance, Biagio Rossetti. The choir was added to the original church by Duke Ercole I d'Este in the late fifteenth century. Its vaulting is decorated with a sort of shimmering variation on Michelangelo's Last Judgment, painted by the late sixteenth-century Ferrarese artist Bastianino. ${ }^{8}$ There was originally a tramezzo, or choir screen, across the nave of the Cathedral, and it was adorned in the mid fifteenth century with life-size bronze statues of St. George and the Dragon; San Maurelio, the legendary first bishop and patron saint of Ferrara; the Virgin; St. John; and a Crucified Christ. Although the tramezzo is gone, these statues by Niccolò Baroncelli and Domenico di Paris, pupils of Donatello, remain, decorating a chapel to the right of the main altar.

The exterior of the cathedral also bears the marks of its history. On the right side of the facade is a Gothic niche with a life-size stone statue of the fourteenth-century marquis of Ferrara, Alberto d'Este. This statue was erected by order of the communal government in 1393 in honor of a very important papal bull which the marquis had won for the city during a pilgrimage to Rome two years earlier. The text of this bull, the Bonifaciana, is inscribed in Gothic lettering beside the niche. The statue of Alberto has an appealing geometric simplicity which gives it something of the aura of a Brancusi. Originally, however, its appearance was more splendid: the marquis held a baton, the symbol of his title as signore, or ruler of the city, in his right hand, and his long robe, which still has traces of an incised brocaded design, and the diadem on top of his cowl were probably gilded.'

Attached to the southern flank of the Cathedral which faces out onto the central square of the city, the Piazza Trento-Trieste, were the shops of the strazzaroli, or cloth merchants (Figure 2). In the early 1470 s their wooden booths were transformed into a graceful Renaissance arcade, the roof of which became a balustraded balcony from which public festivals could be viewed in the square below. ${ }^{10}$ At the eastern end of the cathedral, beside the main apse, rises the sturdy, red and white marble, four-story campanile or bell tower (Figure 3). This structure 
took almost one hundred and fifty years to complete. Although first discussed in 1412, the tower was actually begun in 1451 during the reign of the first duke of Ferrara, Borso d'Este. The first three stories of the tower were probably designed by Leon Battista Alberti, a correspondent and humanist client of Borso's predecessor and half-brother, Leonello. The robust harmony, particularly of the tower's lower three stories and its more classically proportioned orders reveal the campanile's Renaissance origins.

The eastern end of the town square was closed by the loggia of the shoemakers. This was eventually replaced in the late eighteenth century by a theater, which today has become a bookstore. The street which runs out of the eastern end of the piazza, the Via Mazzini, originally the Via Sabbioni, was the street where the Jewish moneylenders lived. In the seventeenth century, the Via Mazzini and the parallel Via Vittoria were closed off by impressive gates to become Ferrara's ghetto. Although the imposing barriers that once held the Jews safely captive in their neighborhood are long gone, the history of the Via Mazzini lives on, for it is here that the synagogue attended by the Finzi and Contini families, as well as Giorgio Bassani, is located. The colonnaded entrance to this temple is very unassuming, marked only by a large modern plaque, set into the wall beside the simple enframed wooden doorway. This marker bears the names of the dozens of Jews of Ferrara murdered by the Nazis. ${ }^{11}$ At the southeastern corner of the piazza is the church and cloister of San Romano. This graceful red brick structure was first built in the eleventh century as a Benedictine monastery. It then came under the protection of the Este at the very end of the thirteenth century and they saw to its rebuilding in 1407. Although San Romano has been renovated several times since then, it still retains a relatively simple, somewhat spindly Gothic appearance. The church and its cloister have been deconsecrated and are currently used as ad hoc exhibition spaces. The Via Romano runs south from the Piazza Trento Trieste towards the Po. And, as one local guidebook puts it, this arcaded street with numerous quattrocento houses and shops, is one of the most engaging in the city.

The buildings on the south side of the square, which alas, include a MacDonalds, really give no hint of what was originally there. Here, the communal prison and the palace of the podestà, or external mayor, were first built in the thirteenth century. These buildings were later incorporated into the more imposing towered Palazzo della Ragione, or Palace of Justice, which added civic law courts and a meeting hall for the larger communal council to the existing prison and podestal quarters. The fourteenth-century palace was obviously an important symbol of the civic government. Clustered around it were notarial offices and the tables of the moneychangers. ${ }^{12}$ Running along the western flanks of this palace was the Via San Paolo, now called the Corso Porta Reno. This street was originally named for the Carmelite church of San Paolo that is adjacent to the street, about halfway down towards the Via Ripagrande. This church faces onto the small Piazzetta Schiatti, named after the sixteenth-century Ferrarese architect Alberto Schiatti, who rebuilt San Paolo after it was destroyed in an earthquake in 1570. Although the church has changed, there is still a wonderfully refined Renaissance cloister beside it, and its campanile, which was built by the Leuci family, stands as one of the few surviving defensive familial towers in the city.

The entrance to the Corso Porta Reno is marked by a three-story clock tower, the ground floor of which houses an exclusive antique shop. This tower, constructed in the seventeenth century 
by Giovanni Battista Aleotti, holds one of the earliest surviving public timepieces in the city.

The west side of the Piazza Trento Trieste is dominated by what is today the Palazzo municipale or city hall (Figure 4), built on the site of two very important medieval structures. The first of these was the so-called Torre di Rigobello, a tower probably dating from the late thirteenth century, site of the first public clock in Ferrara. The second building was the Este palace, a structure that was eventually expanded into what became known as the Palazzo della Corte.

The Este came to power in 1264, when Obizzo II d'Este was elected signore of the city by the Savi, or town council. ${ }^{13}$ The family already held the feudal rank of marquis, but in terms of political power, this was an empty title. In contrast, the post of signore of Ferrara, granted by the communal government, gave Obizzo sovereign dominion over the city and its territories and represented one of the primary foundations of the family's local authority. Although the title of signore became effectively hereditary almost immediately, this office could theoretically be denied to the family at any time, and actually was briefly withdrawn in the third decade of the fourteenth century. Therefore, the Este sought other, more permanent feudal titles to solidify their control. Since Ferrara was technically a papal state, other rights of rulership necessarily had to come from Rome. To that end, the Este sought and, beginning in 1329 , received the title of papal vicar, that is, principal secular representative of the papacy in the city. Until the middle of the fifteenth century, this title, conjoined with the communal office of signore and the feudal designation of marquis, were the foundations of Este authority within the city of Ferrara. ${ }^{14}$

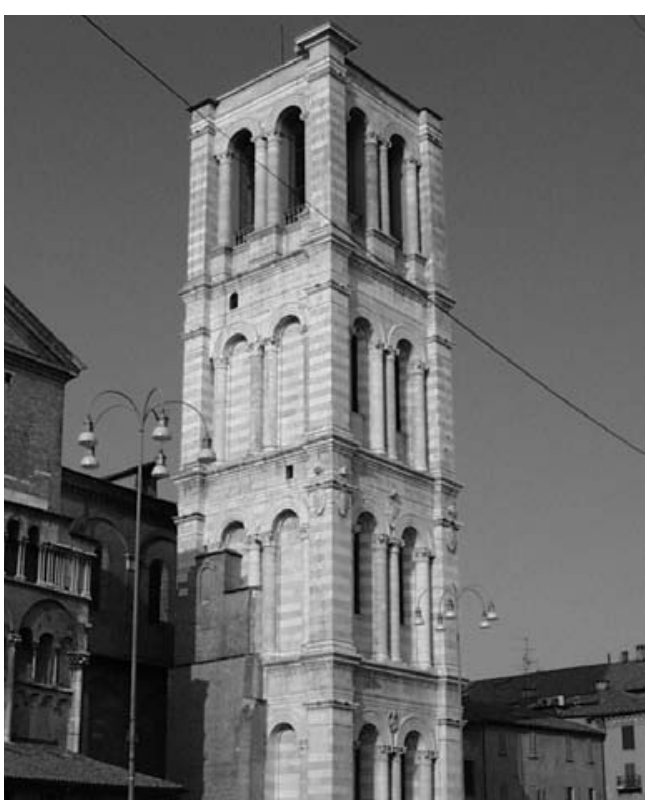

Fig. 3.

Campanile of the Cathedral of St. George, seen from Piazza Trento-Trieste. (Photo K. Williams)

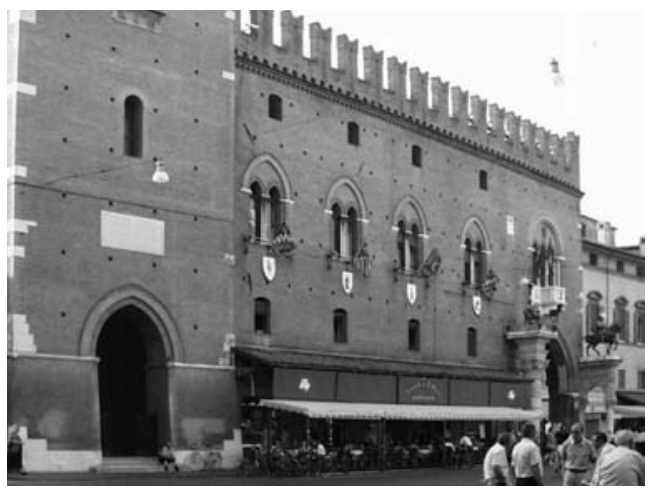

Fig. 4.

Facade of the Palazzo municipale, or city hall, Ferrara. (Photo K. Williams) 
The Palazzo della Corte on the main square of Ferrara was an important symbol of Este authority. As such, it was constantly being expanded and renovated throughout the course of the fifteenth and sixteenth centuries. In spite of its symbolic importance, however, in its fourteenthcentury form, the palace did not offer much in the way of protection against armed invasions or popular insurrections. This fact was brought home to Alberto and his elder brother Niccolò II in 1385 when the people of Ferrara rioted over unfair taxes. ${ }^{15}$ The focus of the Ferrarese anger was actually not the Este but rather one of their subordinates, Tomaso da Tortona. Contemporary chronicles tell us that the crowd that gathered in front of the Corte demanded that Tomaso be turned over to them. Alberto tried to appease them by surrendering the communal tax records, but though the mob quickly burned the ledgers, their anger was still unassuaged. Alberto then descended into the square and tried to calm his rebellious subjects, but this too proved futile, and so, finally, to save the palace and all of its occupants from destruction, Tomaso was delivered to the seething masses, who promptly tore him limb from limb and ate his heart and liver. This uprising impressed the Este with the vulnerability of their living quarters and the necessity of having a fortified retreat nearby. And so, on the Feast of Saint Michael, 1385, the foundation stone for a huge new fortress was laid just north of the Palazzo della Corte. The building, which became known as the Castello di San Michele or the Castelvecchio, was designed by Bartolino Piloti da Novara, an engineer who had worked for the Este since at least 1368. ${ }^{16}$ The arms of Niccolò II and Alberto are still visible on the Torre dei Leoni on the northeast corner of the castle. This massive structure, which still stands today, is one of the most recognizable monuments of medieval Ferrara and one of the finest examples of a late medieval urban citadel in all of Italy. The building has undergone significant alterations. Some of these were necessitated by misfortunes, such as the explosion of a store of gunpowder in one of the towers during the late fifteenth-century Venetian war, or the destruction of another tower by the terrible earthquake of 1570; others were the result of conscious planning.

Perhaps the most important transformation which the Castello underwent, however, is not really visible on the outside. Starting at the end of the fifteenth century, the interior of this fortress, which had initially been built as a temporary retreat for the ruler and his family and a more permanent garrison for troops, was reorganized and redone with the intention of turning it into a more habitable fortified noble residence. This was a lasting change and, although access to the interior of the Castello is limited, some of the flavor of the Renaissance apartments can still be seen in the painted vaults of the late sixteenth-century Sala dei Giochi and the nearby Sala dell'Aurora. Today, the Castello is surrounded by an impressive, if somewhat polluted, moat that throughout most its history emptied directly into a canal connected to the system of waterworks outside the city fortifications, and from there to the Po. In addition, flower and fruit gardens planted to the north and west of the castello were connected through a green corridor to a tree-lined road along the inside of the city walls. This network of park-like promenades, together with the moat and canal system, was designed not only for the pleasure and convenience of the court, but also as a means of allowing the prince and his court to move about Ferrara without actually having to travel through the city streets.

Nexus Network Journal - Volume I, 1999 


\section{The legacy of the Este}

By the time of Alberto's death in 1393, and the succession of his minor son, Niccolò III, Este rule was firmly established in Ferrara. A new wall was built in the early portion of the fourteenth century that embraced the Cathedral and the Castelvecchio, and the outline of these late medieval fortifications is visible today in the path of the Corso Giovecca and Cavour. Alberto had extended the family's presence in the city and its surroundings through the construction of three important buildings, two of which survive. The first of these was the Palazzo Paradiso on the what is today the Via Scienza (Figure 5). Built at the edge of what had been the zone of the Byzantine castrum, this palace was primarily used as a residence by the cadet branch of the family or for noble visitors. The Paradiso survives in a much altered state, having served at one point as the home of the Ferrarese Studio, or University, and now as the home of the communal library, the Biblioteca Ariostea. The building has been renovated over the last ten or fifteen years, and in the course of these renovations huge cisterns were uncovered in the building's central courtyard, and a fairly extensive cycles of early quattrocento frescoes found in two of the main ground floor rooms, the room of Hercules and the room of the emperors. ${ }^{17}$

In addition to this town palace, Alberto also built a villa, Belfiore, to the north of the fourteenth-century circuit of walls. This was the first of what was to become an impressive circuit of Este delizie, or rural retreats. ${ }^{18}$ The rationale for creating these often very elaborate structures was three-fold. First, they provided lodging for the family and its aristocratic guests at strategic point throughout the ducal lands. Second, in the summertime, they provided a cool alternative to the heat and noise of the often malodorous urban environment of Ferrara proper. Finally, they frequently doubled as hunting lodges, providing bases from which the Este and their guest could engage in this most aristocratic of sports. Belfiore, for example, was surrounded by fish ponds and gardens, and was adjacent to the massive ducal hunting preserve known as the Barco, a park famous for its variety of natural and stocked game. ${ }^{19}$ The villa of Belfiore, which has unfortunately vanished, was greatly expanded first by Alberto's son, Niccolò III, and then by Niccolò's sons, Leonello, Borso, and Ercole I d'Este. Along with the more distant delizia of Belriguardo, of which only a fragment remains, Belfiore was celebrated by the Bolognese humanist Giovanni Sabadino degli Arienti in a long panegyric treatise dedicated to Ercole, On the Triumph of Religion. ${ }^{20}$ The palace described by Sabadino was a lavish place with dozens of painted rooms, colonnaded loggias, and secret courtyards and gardens, a true pleasure dome in a terrestrial Garden of Eden. One of the most splendid spaces in Belfiore was a small studiolo begun by Leonello and completed by his half-brother and successor, Borso. The main decorations in this private princely study were intricate intarsia cabinets and tables and a cycle of muses painted by a number of court artists, including Cosmè Tura. Most of these muses have survived, but are now dispersed among museums in London, Budapest, Berlin, Milan and, very recently, Ferrara. Two paintings of extraordinary ladies, Urania, by a follower of Tura, and Erato, by Sienese artist Angelo Maccagnino, which had been part of a private collection in Florence, were given to the National Museum in Ferrara as part of a bequest from the Strozzi-Sacrati families. These paintings by two different artists illustrate the idiosyncratic, metallic, almost mannered style favored by the mid-fifteenth-century Ferrarese court. ${ }^{21}$ 
The third building that Alberto constructed was a modest suburban palace with a small garden and loggia behind it, near to the very ancient monastery of Santa Maria in Vado and the Church of Sant'Andrea. ${ }^{22}$ This building, on the Via Scandiano, is the famous Palazzo Schifanoia. ${ }^{23}$ The Schifanoia, whose name means "banish cares", was expanded during the reigns of Borso and Ercole I. The long brick façade of the palace is very unassuming, although in the fifteenth century it would have been covered with stucco and painted with a repeating geometric design (Figure 6). Fragments of these decorations are still visible on the interior of the place. The painted Renaissance facade would have provided an imposing backdrop for the periodic jousts and festivals that took place in the narrow piazza in front of it. Today, however, the only really distinguishing external feature of the Schifanoia is its monumental main doorway, which is framed by fluted marble pilasters decorated with music-making putti and the Borsian emblem of the unicorn. The doorway is crowned by a massive relief of the Este coat-of-arms, once brilliantly painted, which is set into a classicizing aedicule capped by Borso's emblematic unicorn. ${ }^{24}$

The interior of the Schifanoia, which is today a museum, is something quite a bit more memorable. On the topmost floors, remains of late fourteenth century stucco and painted decorations are still visible. But it is the piano nobile, where the ducal apartments and staterooms decorated in the time of Borso are located, that is the most impressive. Here one finds the Sala degli Stucchi, its richly painted stucco frieze ornamented with the Este arms, standing cherubic infants, and seated female virtues. These brilliant, polychrome maidens

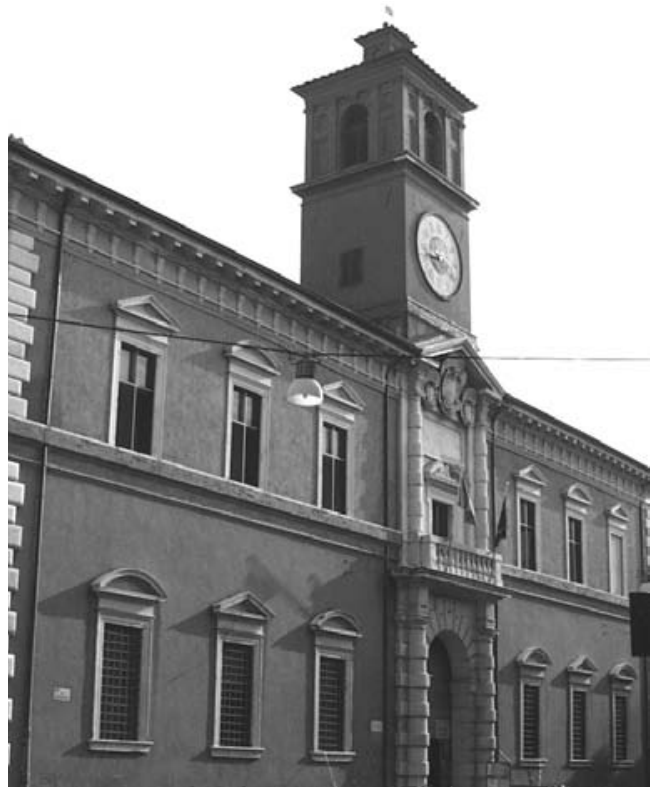

Fig. 5.

The Palazzo Paradiso in Via Scienza, Ferrara. (Photo K. Williams)

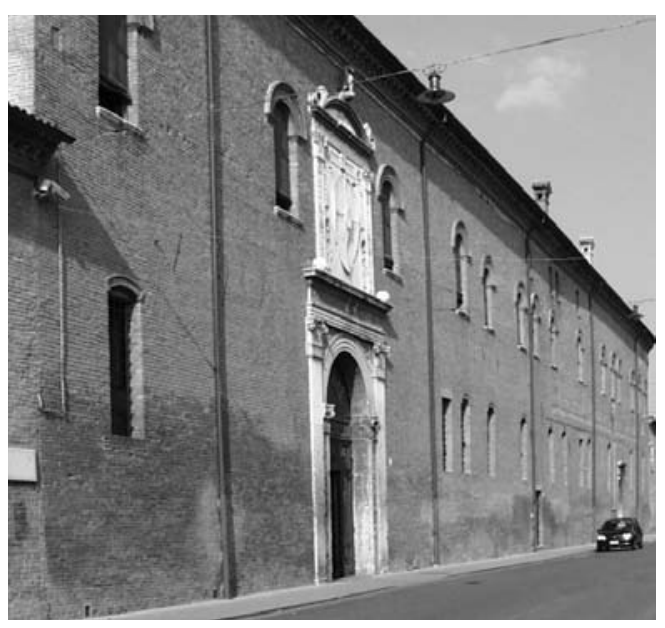

Fig. 6.

Palazzo Schifanoia, Ferrara. (Photo K. Williams)

Nexus Network Journal - Volume I, 1999 
symbolize all of the cardinal virtues but Justice, for when this room was in use as a small audience chamber, Justice would have been exemplified by the duke himself. ${ }^{25}$ Beside this room is the most famous interior space in Ferrara, the Salone dei Mesi. ${ }^{26}$ Stepping into this vast rectangular room is like stepping back into the world of a splendid Renaissance court, the world of one of the most self-consciously magnificent rulers of the fifteenth century, Borso d'Este. The walls of the Salone dei Mesi are covered with a tapestry of frescoes painted by a phalanx of Ferrarese artists, including Francesco del Cossa. Divided into compartments which are separated by painted pilasters, the main program of the room is an enormous cycle of the twelve months, interspersed among which are scenes of parading courtiers and shadowy images of jousts and festivals in the squares of Ferrara. The representations of the months are divided into three layers. The uppermost zone is the realm of the Gods. Here, Venus and Mars, Minerva, Apollo, Mercury and Vesta ride on triumphal chariots drawn by symbolic birds or beasts, like characters in a grand pageant. Surrounding these mythological figures are clusters of contemporary and symbol characters, lovers and musicians, weavers and scholars, merchants and mendicants. These groups are linked to the main figures through the poetic inventions of ancient and medieval writers. The second zone is occupied by the signs of the zodiac, which are flanked by strange figures known as the decans, Arabian astrological deities, each of which was thought to control ten degrees of the celestial sphere. Finally, the images descend to the terrestrial world of fifteenth-century Ferrara where the traditional labors of the months have been replaced by a sort of grand ducal progress. Ferrara and its contada now are cast as an ideal world ruled by an ideal prince, the magnificent Borso. The duke is shown administering justice and receiving petitions, as he would have in the adjacent Sala degli Stucchi, and passing through the central square of the city, distributing alms and greeting ambassadors, but most frequently he and his courtiers are portrayed enjoying the aristocratic pleasures of riding and hunting in the Emilian countryside, a countryside in which, in typical Renaissance fashion, peasants happily and productively labor while their rulers play.

Alberto was succeeded by his naturalized son, Niccolò III, who ruled for over forty years from, 1393 until his death in 1441. It used to be said of this libidinous marquis that "up and down the Po, all were the children of Niccolò". Although he did have two legitimate sons late in life, he was succeeded by one of his many natural children, Leonello. Leonello was a bookish sort who was more interested in ancient culture and corresponding with humanists like Alberti than in improving the fabric of Ferrara, although he did make substantial contributions to the Hospital of Saint Anne, not far from the Castello. ${ }^{27}$ Little remains of the original hospital complex, which probably most famous as the sanitarium in which the great Ferrarese epic poet Torquato Tasso was confined. However some of its quattrocento flavor can still be found in its surviving, beautifully peaceful cloister.

Although he may not have been an active urbanist, Leonello did leave one very important mark upon the city. In 1443, two years after his succession to the throne, the Savi of Ferrara commissioned a bronze equestrian image of Niccolò III to be placed upon an arch attached to the facade of the Palazzo della Corte. ${ }^{28}$ This statue was erected beside the palace's main entrance, which became know as the Arco del Cavallo (Figure 7). The Niccolò monument was actually executed by two former pupils of Donatello, Antonio di Cristoforo and Niccolò Baroncelli (Antonio did the rider and Niccolò the horse and base) and was finally installed in 
1451, a year after Leonello's death. There is little doubt that though this monument was paid for by the commune, its form, one of the earliest, free-standing equestrian monuments erected in Renaissance Italy, was actually Leonello's idea, and that he was probably assisted in conceiving of the project by Leon Battista Alberti. The purpose of this statue was to honor Leonello's father, described as "three times author of peace" on the monument's base, and, by association, Leonello, the faithful son and legitimate successor, so-named on the supporting arch. Although the base of the statue is original, the horse and rider were destroyed in the late eighteenth century by occupying French soldiers. Thus what one sees today is an early twentieth-century reconstruction of the statue by a local Ferrarese artist, Giovanni Zilocchi. Even though Niccolò is shown in contemporary clothing, holding a baton, a symbol of both his calling as a condottiere, or mercenary general, and of his office as marquis and signore of Ferrara, the equestrian form of the statue and its classicizing base were obviously meant to recall ancient models like the famous Marcus Aurelius in Rome, a humanistic reference very much in keeping with Alberti's and Leonello's personalities.

\section{The urban contributions of Borso}

In 1450, Leonello was succeeded by his half-brother Borso, a succession that was actually illegal since not only had Niccolò III's two legitimate sons, Ercole and Sigismondo, become old enough to rule (Ercole was 19 and Sigismondo was 17), but Leonello had named his minor son, Niccolò di Leonello, as his legal heir and successor. Despite these potential obstacles, Borso's accession to the titles of signore and papal vicar were quickly ratified and counter claims denied. Given the problematic nature of his succession, Borso set out to reinforce his position through a program of image management and concrete reform. The marquis actively sought to improve the position of the Este in the broader world of peninsular feudal politics by enhancing his imperial and papal titles. In this pursuit he was extraordinarily successful, for he was named hereditary Duke of Modena and Reggio by Frederick II in 1452, and first Duke of Ferrara by Pope Paul II in 1471, the year of Borso's death. In addition to these feudal strategies, Borso sought to legitimate his reign by identifying himself as an ideal ruler. To that end, he consciously promoted an image of himself as an embodiment of Justice. He introduced concrete judicial reforms and had the communal statutes significantly revised. He also used more symbolic means of crafting his identity. This is visible in the March field of the Schifanoia frescoes and, even more prominently, in the public monument erected in Ferrara in his honor during his own lifetime. ${ }^{29}$ This monument, which was originally erected in front of the Palazzo della Ragione in 1456 but then moved to its present location pendant to the Niccolò statue in 1472, consists of an enormous Veronese marble column with an elegant Corinthian capital supporting a platform on which is placed an almost life-sized, bronze seated, Solomonic effigy of Borso administering justice. The inscription on the monument not only evokes the duke's just character, but also alludes to Virgilian images of a golden age of peace ushered into Ferrara by the actions of this ideal prince. ${ }^{30}$ The statue of Borso, like that of Niccolò, was destroyed by the French in the late eighteenth century and has been replaced by an early twentieth-century reconstruction by Zilocchi. Only the capital and parts of the supporting columnar base are original. The column 
was severely damaged by fire in 1716, and in order to restore it, the papal legate governing Ferrara ordered that tomb slabs from the Jewish cemetery be cut into rings and used as replacements for the lost section of the base.

Borso's other contributions to the fabric of the city consisted of the decorations of the Schifanoia and two larger urban projects. ${ }^{31}$ Originally there were two small islands in middle of the main branch of the Po which flowed by Ferrara. One of these, located upstream at the extreme western end of the city, became the site of a famous sixteenth-century Este villa known as Belvedere. This villa was destroyed and the island absorbed into the main fabric of the city in the early seventeenth century, when Pope Paul v Borghese built a huge stellar fort on the site, remnants of which can still be seen in the bastions and earthworks in the southeastern corner of Ferrara. The second island, however, disappeared considerably earlier. This island was the location of a very important monastic foundation, the Convent of San Antonio. The monastery, which still exists and can be visited with permission, possessed the remains one of the few saints in the history of the Este family, the Blessed Beatrice II, and was, therefore, traditionally an important focus of familial largesse. In the course of the early fifteenth century, however, the branch of the Po which flowed north of San Antonio had begun to silt up, until by Borso's time, the island was no longer an island. Thus, one of Borso's most important urban projects was really an acknowledgment of an inescapable geographic fact. The river bed was converted into a street, the Via Ghiara, or street of stones (today the Via di XX Settembre), and a new wall was built south of the convent. As a final recognition of the absorption of the area known as the Polesine di San Antonio into the city proper, its residents were granted full citizenship in the early 1460s.

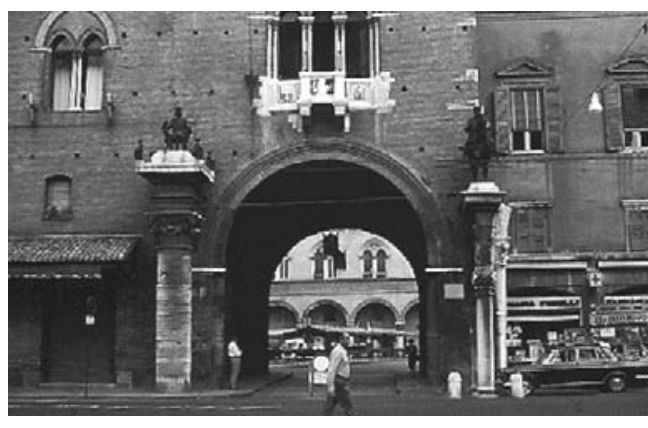

Fig. 7.

Arco del Cavallo, Ferrara.

(Photo K. Williams)

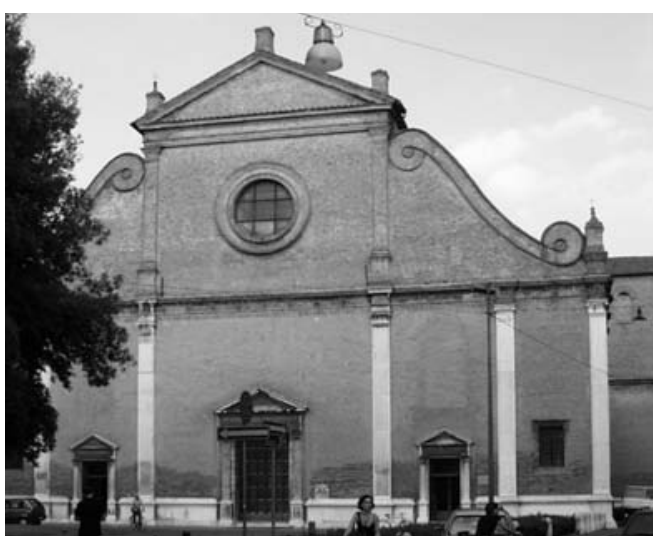

Fig. 8.

The church of San Francesco, Ferrara. (Photo K. Williams) 
Borso's other principal urban project within the city was encouraging the construction of palaces by some of the most wealthy and influential families in Ferrara on a new street, the current Via Savonarola, which ran east-west between the Church of San Francesco (Figure 8) and the Clarissian convent of Corpus Domini. Both of these religious foundations were very important to the Este. Besides being the principal Franciscan church in the city, the church of San Francesco was also the site of a family chapel where several important members of the clan, including Alberto d'Este, were buried. ${ }^{32}$ The building that exists today primarily reflects the designs of Biagio Rossetti. The church has a simple, typical basilican facade that is austerely ornamented with pilasters and elegant volutes. Its large, light-filled interior is still adorned with a few fragments of fifteenth- and sixteenth-century frescoes. The Convent of Corpus Domini, or Corpus Christi, as it was also known, was founded by Niccolò III in 1415 for a group of Augustinian nuns. Throughout the course of the fifteenth and sixteenth centuries this foundation was particularly favored by Este women and, in fact, became a sort of female familial mausoleum. The convent and church survive in fairly good condition and although parts of it remain in clausura, the building can be visited on a limited basis.

The Via Savonarola became a street favored by wealthy merchants and court bureaucrats. The palace directly across from San Francesco, for example, was built in the mid-1440s by the very successful merchant and civic official Giovanni Romei. The Casa Romei, as it is called today, is a sculpture museum. In its restored form it allows one to see the sorts of spaces in which the wealthy bourgeoisie lived in a fifteenth-century Ferrara. The core of the palace is a large, central, arcaded court of honor, adorned with an enormous terra-cotta rosette (Figure 9). From this courtyard one can enter the family's various public and private chambers. Rather large portions of the original lush decorations which adorned the interior walls of the palace apartments remain. Perhaps the most impressive of these are the frescoes in the Room of the Sibyls, a chamber which was probably part of the women's quarters in the palace. Here, stately prophetesses with long scrolls are ranged around the walls in front of a painted fence through which we view a luxurious hedge of greenery, while festive putti cavort in the frieze up above. The room evinces the schizophrenic air of both pedantry and delight that is characteristic of fifteenth-century Ferrarese culture. ${ }^{33}$

Finally, in the early 1460s, Borso introduced a community of Carthusian monks into Ferrara and settled them in a new monastic church, San Cristoforo, and cloister which he had built just north of the city. ${ }^{34}$ The duke also had a residence erected close to the Carthusians. He decorated some of this palace's rooms with scenes from the lives of ascetic, hermit saints. Undoubtedly Borso, who wore jewels and golden brocades even when riding in the countryside and who sought to embody the concept of princely magnificence in his every action, hoped that the foundation of this monastic complex would serve as evidence of his personal piety, and that the prayers of the otherworldly Carthusians, coupled with his own penitential prayers before images of self-denial and asceticism, would compensate for his worldliness and speed the eventual passage of his soul into heaven. When Borso died he was buried in the cloister. Although his palace is gone, remnants of his tomb remain. The Certosa complex was greatly expanded in the sixteenth century, with a new church built according to the designs of Biagio Rossetti. This is the form in which we see it today, a huge, rather austere, light-filled basilican structure, now surrounded by the main civic cemetery of Ferrara. 


\section{The labors of Ercole}

Borso was succeeded by his half brother Ercole I, a succession which once again was fraught with danger, for, although Ercole's younger sibling Sigismondo fully supported the transition, his nephew, Niccolò di Leonello, disputed Ercole's claims to the throne. Of all of the Este rulers, Ercole probably left the most enduring mark upon the face of Ferrara. ${ }^{35}$ From almost the moment he took possession of the city, he began to alter its appearance. At first, his attentions were concentrated on the ducal palace. In anticipation of his marriage to Eleanora of Aragon, a princess of royal Neapolitan blood, Ercole set about transforming the Corte into a setting appropriate to his new station. He constructed a series of stacked arcaded loggias on the facade of the Torre di Rigobello, transforming the tower into a noble reviewing stand, and had the spandrels of the ground floor and piano nobile arcades adorned with marble reliefs of Roman emperors, two of which survive in the civic sculpture collection in the Casa Romei. ${ }^{36}$ Ercole moved the Borso statue to a location alongside the Arco del Cavallo, transforming the archway into a more classical and imposing entrance. This transformation was probably inspired by memories of the great gateways of the Castelnuovo in Naples, a city where Ercole had spent much of his youth. He added a new courtyard and fountain to the building, the Cortile Grande, situated behind the palace towards the Castello, and had the ducal architect, Pietro Benvenuti degli Ordini, construct a new, covered staircase in the main courtyard, the Cortile della Lastre (Figure 10). This surviving structure, with its arched entrance and canopied landing, lent itself to the demands of court ceremony. Finally, the duke made significant improvements to the interior of the palace, painting and reflooring apartments,

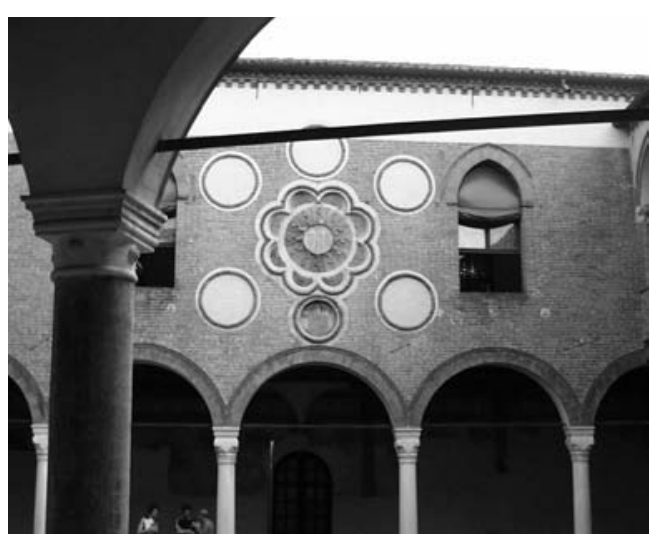

Fig. 9.

Cortile of the Casa Romei, Ferrara. (Photo K. Williams)

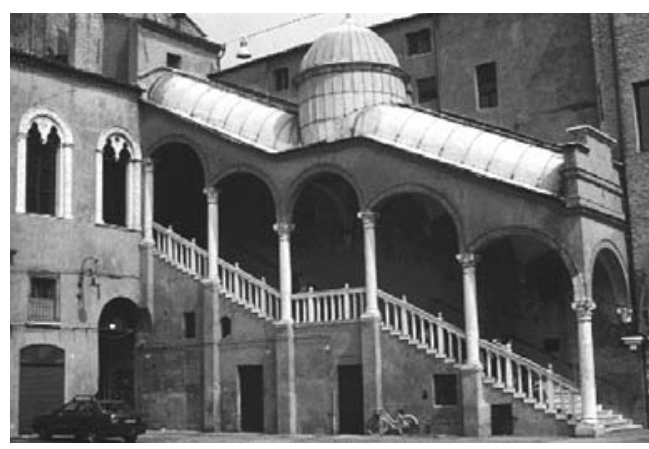

Fig. 10.

Cortile della Lastre, Ferrara. (Photo C. M. Rosenberg) 
offices, and state rooms, embellishing the Sala Grande, a long formal salone on the front wing of the palace facing the bishop's palace. In addition, he replaced what had apparently been a wooden covered passageway connecting the Corte to the Castelvecchio with a new, raised corridor of brick and marble, the Via Coperta. This passageway created two new piazzas. One of these faced west towards the small church of San Giuliano, and was surrounded by shops. The other, the present day Piazza Savonarola, faced east towards the bishop's palace and the city. The construction of the Via Coperta proved to be a very wise precaution, for on the evening of September 1, 1476, while Ercole was absent from the city, Niccolò di Leonello and his supporters, the veleschi, invaded the city of Ferrara and broke into the ducal palace in an attempted coup d'etat. Eleanora and her newborn son, the future Alfonso I, were in the Palazzo della Corte at the time. Contemporary chroniclers report that the duchess was alerted to the invasion by the shouts of the veleschi and the splintering of doors. Frightened and weeping, Eleanora barely had time to grab her child and flee through the Via Coperta into the safety of the Castello. The ambitious Niccolò di Leonello had over-estimated his support. By nightfall, Ercole's loyal brother Sigismondo had rallied a contingent of soldiers and a crowd of citizens and had captured the rebellious prince and many of his supporters. The traitors were imprisoned in the dungeons of the Castelvecchio, and eventually hanged or beheaded. Although the coup had failed, it obviously greatly affected both the duke and duchess, for it was immediately following this incident that Ercole began to convert sections of the Castelvecchio from barracks and storage into appropriately elegant apartments and staterooms. At the same time, Eleonora saw to the creation of her own private suite within the Castello, constructing a bedchamber, anterooms, oratory, study, and secret colonnaded garden on the northern side of the fortress. ${ }^{37}$ The intention of these renovations was clearly to make it possible for the family to live comfortably and safely within the massive, fortified walls of the medieval citadel. The duke also sought to make the environs of the castle more hospitable by constructing a vast walled garden to the north and west of the building, an improvement which required tearing down some of the structures which he had built just a few years earlier and confiscating property from members of his own court. This was actually a pattern which he seems to have followed throughout his reign, adding and altering the ducal residences time and again. Most of this work, except for the Via Coperta, the monumental staircase, the facade of the fifteenth-century ducal chapel, Santa Maria della Corte, and a few arched windows in the courtyard of the Palazzo municipale, has disappeared, but Ercole's grandest and most ambitious project has not.

In the early 1480s Ferrara became embroiled in a war with its northern neighbor and nemesis, Venice. This conflict, which lasted for more than two years, went quite badly for the Ferrarese and their allies, so badly, in fact, that at one point Venetian forces were actually able to advance to the very edge of the city, invading the Barco and sacking Belfiore and the ducal monastic complexes of Santa Maria degli Angeli and the Certosa. At the conclusion of the war, it was apparent to Ercole that something had to be done to protect the northern flank of Ferrara, but the ducal treasury was sorely depleted, and so any plans that he may have had for strengthening the city defenses were deferred for almost a decade. Finally, in 1492, spurred on by rising tensions with the Serenissima, Ercole decided to construct an enormous new set of walls and fortifications to the north of the existing city. These new walls embraced sparsely inhabited 
northern suburbs, as well as the villa of Belfiore and the monastic foundations which had been so disastrously pillaged by the Venetians. Even as he expanded the city fortifications, Ercole also sought to convert the now incorporated suburbs into the fabric of Ferrara proper and to turn the space into a true urban environment. What ensued was the creation of the largest realized example of urban planning of the entire fifteenth century, the Erculean Addition.

The lineaments of Ercole's plan are clearly visible in the streets and squares of the northern half of the city. Some streets, like the Via Palestro/Borso which ran out from the old walls to the Certosa, already existed in the suburbs before the duke undertook his project, but these were subsumed into a larger pattern. ${ }^{38}$ The main north-south axis of the plan was defined by the Via degli Angeli, today the Corso Ercole I d'Este, an extraordinarily wide, noble street which ran from the Castello gardens past Santa Maria degli Angeli to the gates of Belfiore and the Barco. The principal east-west thoroughfare was the only slightly more modest Via Prioni, today the Corso Po/ Biagio Rossetti/ Porta Mare, which connected two fortified gates, the Porta di San Benedetto on the west and Porta di San Giovanni Battista on the east. Other considerably more modest residential streets were also added or created out of existing paths: the Via Mortara on the east, the Via Arianuova on the north, and the Via Mirasole/ Ariosto on the west. The resulting plan was not a perfect grid because it took into account defensive considerations, significant ecclesiastical structures, and existing settlement patterns. Nonetheless, it provided a sense of regularity that both merged and contrasted with the older, more organically evolved sections of the city. Ercole did not stop, however, with laying out streets. For both economic and defensive reasons, he also wanted the area to be inhabited as rapidly as possible. To that end, he encouraged the construction of both grand aristocratic palaces and modest one- and two-story dwellings that seem to have been built for and occupied by members of the artisan class, like those along the Via Mirasola/Ariosto. Most of the noble palaces were constructed along the Via degli Angeli and Via Prioni, and around the huge Piazza Nuova, today called the Piazza Ariostea. These include grand buildings such as the Palazzo Massari and Palazzo Giulio d'Este, with their typical brick facades and applied stone corner pilasters and elegant window surrounds. Even grander, however, were those built at the crossroads of via Prioni and via degli Angeli. Three of these survive: the Palazzo Turchi di Bagno on the southeastern corner, notable for it brick and terra cotta work, as well as its marble doorway; the Palazzo Prosperi-Sacrati on the northeastern corner, distinguished by its aedicular porch enframed by free-standing Corinthian columns crowned by seated putti carved by Antonio Lombardi between 1506 and 1516; and the Palazzo dei Diamanti (Figure 11), distinguished by its ornamental corner pilaster and balcony, monumental doorway and signature diamond-cut masonary. The Palazzo dei Diamante, which is today the home of the national picture gallery, or Pinacoteca nazionale, of Ferrara, was built by Ercole for his brother Sigismondo. The unique appearance of the building evokes a sense of fortified strength appropriate for a prince who still depended upon his reputation as a soldier for a sizable part of his income, and for the defensive subtext of the Addition as a whole, but also refers to one of the principal Este emblems, the diamond ring. 


\section{The saga of a column}

One final defining element of the Erculean Addition was the huge square, the Piazza Nuova (today called the Piazza Ariostea), built beside the road going out towards the Certosa, the current Via Palestro. There is some evidence that this piazza, which was originally supposed to house a market and hence contribute to the economic life of the new addition, was intended to be surrounded by arcaded palaces like the Palazzo Rondinelli and Palazzo Bevilacqua. Although the scale of this space dwarfs such structures, the creation of what would have been, in essence, an arcaded perimeter around the piazza would have given it an appropriately classicizing air. Today in the center of the square there is a massive, weathered, white marble column on top of which is a statue of the famous Ferrarese poet Ludovico Ariosto. The saga of this columnar monument can serve as a final demonstration of how the history of a place is written on its stones. ${ }^{39}$

Simultaneous with the conception of the Piazza Nuova, Ercole decided to commission an enormous columnar equestrian monument in his own honor to be erected in the center of the square as a sort of imperial-scale signature of authorship. The appearance of the monument, designed by Ferrarese painter and architect Ercole de' Roberti, is only known through a drawing and a woodcut. Two massive columns measuring 22 Ferrarese feet high by 4 Ferrarese feet across (or just a little less than 29 modern feet high by 5 modern feet across) were cut from Veronese marble and shipped to Ferrara. In the process of unloading the columns, one fell into the Po and was never recovered, while the other was transported with great difficulty to the piazza. In the meantime, Ercole de' Roberti died, and no local sculptor emerged who was capable of realizing and casting the colossal horse and rider which were to crown the monument. In an effort to find a suitable replacement, the duke wrote to his ambassador in Milan in 1500 saying that he had heard about a great clay horse that a Florentine artist called Leonardo had made for an aborted monument to Francesco Sforza. Ercole wondered if it could be sent to Ferrara to serve as the model for his own monument. Unfortunately, Leonardo's colossal horse was destroyed by French archers before it could be sent. ${ }^{40}$ After Ercole I's death, interest in his monument waned and the column and its base remained abandoned and neglected in the center of the square throughout the sixteenth and most of the seventeenth centuries. In 1598, the main Este line died out and control of the duchy reverted back to the papacy. The Este family moved to Modena, where it held an imperial title, and Ferrara, no longer a capital city, became a marginalized town governed by an often absentee papal legate. The history of the Ercole monument

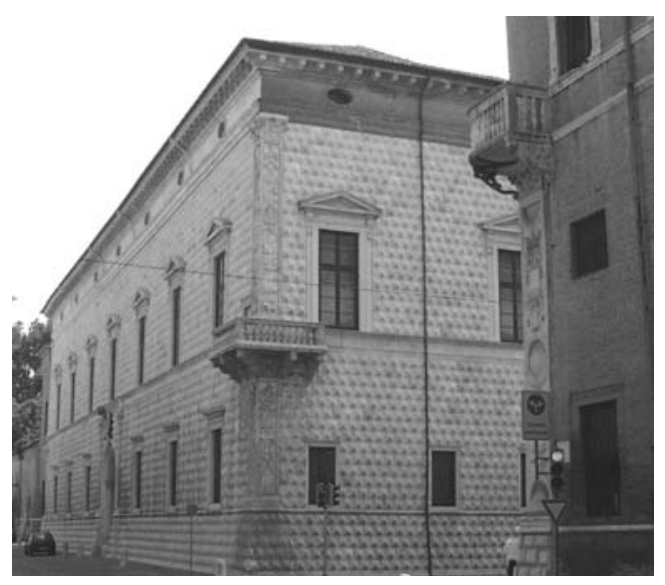

Fig. 11.

Palazzo dei Diamanti, Ferrara. (Photo K. Williams) 
reflects this neglect. In 1639, the half buried column was actually broken in two by a fireworks accident in the square. And so it remained until 1670, when a new papal legate, Cardinal Nipote Sigismondo Chigi, decided to revitalize the Piazza Nuova by embellishing the square and establishing a weekly livestock market on the site. As part of this project, Chigi decided to erect a monument to his uncle, Alexander VII, at the center of the piazza. In order to do so, the Cardinal disassembled an earlier monument to Alexander in the Piazza Trento-Trieste, and had its bronze effigy of the pope transported to the Piazza nuova. Next, he excavated the broken column from the Ercole monument and had it repaired and recut. Working from a drawing by Comacchese architect and painter Cesare Mezzogori, local sculptors Andrea and Michele Bresciani embellished the column with a carving of climbing oak branches. Finally, the repaired and decorated column was placed atop a drastically reduced version of the original Erculean pedestal and, on 21 June 1675, the bronze seated effigy of Alexander VII was hoisted to its top amid much ringing of bells and joyous celebration. More than 180 years after the Piazza Nuova had been designed, it finally received a crowning centerpiece.The statue of Alexander VII remained in place until the very end of the eighteenth century. On 8 October 1796, invading French troops pulled it down and transported it to the Castelvecchio, where it was temporarily stored in a horse stall. Eventually, this effigy, along with the Borso and Niccolò statues, was melted down for canon. Just a few weeks after the figure of Alexander was destroyed, a carved image of Liberty was placed on the column. According to Luigi Napoleone Cittadella, the installation ceremony was attended by two thousand French troops, the National Guard, and General Napoleon himself. ${ }^{41}$ The monument now stood as an emblem of the displacement of the ancient regime - Liberty had replaced despotism.

Liberty's reign, however, was very short lived. On 22 May 1799, invading Austrian forces pulled the statue down and destroyed it, leaving the column without a crowning effigy until the second decade of the nineteenth century. In 1808, the Department of the Lower Po decided to erect a monument to Napoleon in the Piazza Nuova. ${ }^{42}$ To that end, the Prefect of Bologna, Signor Scopoli, commissioned the neo-Classical sculptor Giacomo De Maria, a pupil of Antonio Canova, to carve a colossal Veronese marble statue of emperor. It took two years for this image to make it to the top of the column and then four more for it to suffer the same fate as those which had preceded it. On 14 May 1814, the marble effigy was pulled down, broken into pieces, and buried, in a symbolic exorcism of the demons of Napoleonic oppression. The final episode in the history of the monument dates from the 1830s, the period of the Risorgimento. On 23 November 1833, a statue of Lodovico Ariosto was erected in the Piazza Nuova and the square was rechristened the Piazza Ariostea. The new statue apparently deteriorated fairly rapidly, for it was replaced in 1881 by a portrait of Ariosto carved by sculptor Ambrogio Zuffi. It is this statue which adorns the piazza today. In its final incarnation, the remnants of the last Este monument became a memorial not to a political or spiritual leader (Ercole I, Alexander VII, or Napoleon) or to an idealist abstraction ("liberty"), but to a literary hero, Ariosto. During the Risorgimento, much of Italy had begun to redefine its past in terms of its cultural heritage - a nationalistic vision of history which has continued up to the present day. The final incarnation of the last Este monument is evidence that Ferrara had begun to conceive of its historic grandeur in terms of the brilliance of its writers and humanists and the cult of the artist as demi-god. The footsteps of the prince had finally been replaced by those of the poet. 
Notes.

1. Francesca Bocchi, "Ferrara, una città fra due vocazioni: Urbanistica e storia: da piazzaforte militare a centro commerciale," in idem, Attraverso le città italiane nel medioevo, Casalecchio di Reno, 1987, pp. 147-53.

2. By the fifteenth century the Este had assembled an extraordinary fleet of luxury craft for traveling through the inland waterways. The grandest of these were the ducal bucintori, which were fitted out with sails and oars and were often elaborately decorated and furnished. See Thomas Tuohy, Herculean Ferrara: Ercole d'Este, 1471-1505, and the Invention of a Ducal Capital, Cambridge, 1996, pp. 154-60.

3. For a discussion of the hydraulic history of the Val Padana and its impact on Ferrara, see Marco Bondesan, Renzo Ferri and Marco Stefani, "Rapporti fra lo sviluppo urbano di Ferrara e l'evoluzione idrografica, sedimentaria e geomorfologica del territorio," in Anna Maria Visser Travagli, ed., Ferrara nel medioevo, topografia storica e archeologica urbana, Casalecchio di Reno, 1995, pp. 27-42.

4. Bocchi, "Ferrara, una città," (cited in note 1), pp. 153-61.

5. For a history of the cathedral and its Romanesque sculpture, see Werther Angelini, ed., La cattedrale di Ferrara, Ferrara, 1982, and articles in Angiola Maria Romanini, ed., Nicholaus e l'arte del suo tempo: in memoria di Cesare Gnudi, Ferrara, 1985.

6. For the most recent discussion of these organ shutters, see Stephen Campbell, Cosmè Tura of Ferrara, New Haven, 1997, pp. 131-61.

7. On Ferrarese illuminations, see Hermann Julius Hermann, La Miniatura estense, ed. Federica Toniolo, Modena, 1994, and Federica Toniolo, ed., La Miniatura a Ferrara dal tempo di Cosmè Tura all'eredità di Ercole dé Roberti, Modena, 1998.

8. On Bastianino and the apse decorations, see Giorgio Padovani, "L'abside rossettiana e il 'Giudizio Universale del Bastianino," in La cattedrale di Ferrara, ed. Werther Angelini, Ferrara, 1982, pp. 413-27, and Bastianino e la pittura a Ferrara nel secondo Cinquecento, Bologna, 1985.

9. This statue and its history is discussed in Charles M. Rosenberg, The Este Monuments and Urban Development in Renaissance Ferrara, chap. 2, Cambridge and New York, 1998

10. Interestingly enough, hidden behind the row of shops, incised into the flank of the cathedral are the earliest statutes of the city of Ferrara. These were already covered over in the fourteenth century. Cf. Adriano Franceschini, Frammenti epigrafici degli Statuti di Ferrara del 1173 venuti in luce nella Cattedral, Ferrara, 1969.

11. The classic study of the Jews in Ferrara is Abramo Pesaro, Memorie Storiche sulla comunità Israelitica Ferrarese, Ferrara, 1878-80 (reprint: Bologna, 1986). For a brief discussion of the Jews in Ferrara and a description of the ghetto, see Maria Giuseppina Muzzarelli, "Gli ebrei," in Storia illustrata di Ferrara, ed. Francesca Bocchi, vol. 2, San Marino, 1987, pp. 465-72.

12. For a view of the Palazzo della Ragione and its surroundings, see the illumination from the Libro dei giustiziati, Ferrara, Biblioteca Comunale Ariostea, ms. Cl. I, cod. 404, ff. 16v-17r, illustrated in color in Storia illustrata di Ferrara (cited in note 11) vol. 2, p. 435, fig. 3.

13. The best general survey of the history of Ferrara from the middle ages through the reign of Ercole I d'Este in English remains Werner L. Gundersheimer, Ferrara, the Style of a Renaissance Despotism, Princeton, 1973.

14. The Este held separate titles in Modena and Reggio as signori and Imperial vicars.

15. On this insurrection, see John Law, "Popular Unrest in Ferrara in 1385," in The Renaissance in Ferrara and its European Horizons, eds. J. Salmons and W. Moretti, Cardiff and Ravenna, 1984, pp. 41-60.

16. On Bartolino da Novara, see Muiella Montanari, "Bartolino da Novara”, Arte lombarda 92-93 (1990), pp. 21 30. On the image of the fortress as a sign of signorial domination, see Joanna Woods-Marsden, "Images of Castles in the Renaissance: Symbols of 'Signoria'/Symbols of Tyranny," Art Journal 48.2 (Summer, 1989), pp. 130-7.

17. For a history of the Palazzo Paradiso, see Alessandra Chiappini, ed., Palazzo paradiso e la Biblioteca ariostea, Rome, 1993.

18. On the Este villas, hunting lodges and suburban palaces, see Gianna Pazzi, Le delizie estensi e l'Ariosto: fasti e piaceri di Ferrara nella Rinascenza, Pescara, 1933; Mario Zaniboni, Gli Estensi nelle loro delizie : Ferrara medievale e rinascimentale, mura, torrioni, castelli e delizie, Ferrara, 1987; and Tuohy, Herculean Ferrara (cited in note 2), pp. 142-54.

19. The Barco was celebrated in a poem entitled Dialogus de amoenitate, utilitate, magnificentia Herculi Barchi, 
written by the court poet Lodovico Carbone. Cf. Antonio Lazzari, "Il 'Barco' di Ludovico Carbone," Atti e memorie della Deputazione provinciale ferrarese di storia patria, n.s. 10 (1954): 5-44.

20. This treatise has been published by Werner Gundersheimer, Art and life at the court of Ercole I d'Este: the De triumphis religionis of Giovanni Sabadino degli Arienti, Geneva, 1972. The description of Belfiore and the other great Erculean villa, Belriguardo, appear on pp. 56-72.

21. The cycle of muses from Belfiore was the central focus of a 1991 exhibition held at the Museo Poldi-Pezzoli, Milan, entitled "Le muse e il principe". The catalogue for the exhibition and a second volume of essays, edited by Alessandra Mottola Molfino and Mauro Natale, was published in Modena simultaneous with the exhibition. For a more recent discussion of the Belfiore studiolo and the significance of its decorations, see Campbell, Cosmè Tura (cited in note 6), pp. 29-61.

22. Both of these churches were essentially rebuilt in the fifteenth and sixteenth centuries. Santa Maria in Vado was rebuilt according to designs provided by the painter Ercole de' Roberti in the 1490s. Work progressed on the church throughout the first decade of the sixteenth century under the supervision of the ducal architect/engineer Biagio Rossetti. The church was particularly renowned as the site of a miraculous bleeding host. The Church of Sant' Andrea was also expanded in the early sixteenth century under the supervision of Rossetti. The patronage rights for its cappella maggiore belonged to the Costabili family, one of the most powerful in the city. Andrea Costabili held both communal and ducal office during the reigns of Ercole I and Alfonso I d'Este. He was the patron of the great Costabili Altarpiece painted by Garofalo and Dosso Dossi, one of the gems of the collection of the Pinacoteca nazionale housed in the Palazzo dei Diamanti. For a brief the history of these two churches, see Tuohy, Herculean Ferrara, (cited in note 2) pp. 367-8, 388-9. For a discussion of Ercole de' Roberti's part in the design of Santa Maria in Vado, see Joseph Manca, The Art of Ercole de' Roberti, Cambridge and New York, 1992, pp. 79-83. For Rossetti's involvement at Santa Maria in Vado, see Bruno Zevi, Sapere vedere l'urbanistica. Ferrara di Biagio Rossetti, la prima città moderna europea, Turin, 1971, pp. 222-9.

23. The most complete discussion of the history of the Schifanoia and its decorations are to be found in Ranieri Varese, "Novità a Schifanoia," Critica d'arte, n.s., 17, fasc. 113 (1970): 49-62, and idem, ed. Atlante di Schifanoia. Modena, 1989.

24. Eberhard Ruhmer has suggested that this portal was carved by Ambrogio da Milano and Antonio di Gregorio Campi, possibly after designs by Francesco del Cossa. See Eberhard Ruhmer, Francesco del Cossa, Munich, 1959, pp. 91-2.

25. For the iconography of the Sala degl stucchi, see Charles M. Rosenberg, "The Iconography of the Sala degli stucchi in the Palazzo Schifanoia in Ferrara," The Art Bulletin 61 (1979): 377-83.

26. The bibliography on these frescoes is enormous. The first major discussion of the iconography of the frescoes was by Aby Warburg, "Die Erneuerung der heidenischen Antike ii," Gesammelte Schriften, Leipzig, 1932 pp. 459-81, Italian trans., "Arte italiana e astrologia internazionale nel Palazzo Schifanoia di Ferrara (1912)," in La Rinascita del paganesimo antico, Florence, 1966, pp. 247-72. For a good, comprehensive curent bibliography, see Varese, ed., Atlante di Schifanoia (cited in note 22).

27. For a discussion of the early history of this important charitable foundation, see Adriano Franceschini, "Il Sapore del Sale: Ricerche sulla assistenza ospedaliera nel sec. xv in una città di punta: Ferrara," Atti e memorie della Deputazione provinciale ferrarese di storia patria, 4th ser., vol. 1 (1981), pp. 65-114.

28. For a discussion of this statue and its history, see Rosenberg, Este Monuments (cited in note 9), chap. 4.

29. For a discussion of the Borso monument, see Rosenberg, Este Monuments (cited in n. 9), chap. 6.

30. For the Virgilian references, see Kristin Lippincott, "The neo-Latin historical epics of the north Italian courts: an examination of 'courtly culture' in the fifteenth-century," Renaissance studies, 3.4 (1989), p. 423 n. 25.

31. For a discussion of Borso's urban projects, see Rosenberg, Este Monuments (cited in note 9), chap. 5.

32. On the history and design of San Francesco, see Tuohy, Herculean Ferrara (cited in note 2), p. 276, and Zevi, Sapere vedere, (cited in note 22), pp. 210-21.

33. On the history of the Casa Romei and the Sala dei sibille, see Carla Di Francesco, ed., Le sibille di Casa Romei : storia e restauro, Ravenna, 1998.

34. For Borso's construction of the Certosa and its subsequent history, see Ferdinando Canonici, Storia e descrizione dell'antica Certosa di Ferrara ora Camposanto, Rovigo, 1851; Charles M. Rosenberg, "Per il bene di ... nostra citta': Borso d'Este and the Certosa of Ferrara," Renaissance Quarterly 29.3 (1976): 329-40; and Zevi, Sapere vedere (cited in note 22), pp. 239-46. 
35. The most complete discussions of Ercole's transformation of the city of Ferrara can be found in Zevi, Sapere vedere (cited in note 22); Tuohy, Herculean Ferrara (cited in note 2); and Rosenberg, Este Monuments (cited in note 9), chap. 7.

36. For a view of the Torre di Rigobella after Ercole's renovation, see the late fifteenth-century woodcut reproduced in Roberta Iotti, Gli Estensi. Prima parte. La Corte di Ferrara, Modena, 1997, p. 245. This woodcut also shows the Niccolò and Borso monuments in their location in flanking the Arco del cavallo.

37. Eleanora's apartments in the Castelvecchio may have inspired her daughter Isabella d'Este in the construction of her own studiolo and grotta in Mantua. Unlike Isabella, however, Eleanora does not seem to have been interested in collecting antiquities, nor in developing a complex allegorical program for her study. On the relationship between Isabella's studiolo and the earlier Ferrarese example at Belfiore, see Jaynie Anderson, "What was Ferrarese about Isabella d'Este's Camerino?" in Cesare Mozzarelli, Robert Oresko and Leandro Ventura, eds., La Corte di Mantova nell'età di Andrea Mantegna: 1450-1550, Rome, 1997, pp. 337-52.

38. For a discussion of the Addition, see the sources cited in note 34; Charles M. Rosenberg, "The Erculean Addition to Ferrara: Contemporary Reactions and Pragmatic Considerations," acta: The Fifteenth Century (suny at Binghamton) 5 (1978):49-67; and Carlo Bassi, Marcia Peron, and Giacomo Savioli, eds., Ercole I d'Este: Strada degli Angeli e dei Piopponi. Anticipazioni di ricerche e studi compendiati per un convegno e un libro sui primo 500 anni dell'addizione, Ferrara, 1991. Biagio Rossetti has traditionally been identified as the author of the Addition, see, for example, Ada Francesca Marcianò, L'età di Biagio Rossetti. Rinascimenti di casa d'Este, Rome, 1991. This interpretation has recently been questioned by Rosenberg (cited in note 9) and Tuohy (cited in note 2).

39. What follows is from Rosenberg, Este Monuments (cited in note 9), chap. 8.

40. Philip Grierson has tried to argue otherwise on the basis of the image of a horse and rider which appears on the reverse of a silver quarto struck in Ferrara around 1500. His argument, however, seems tenuous at best, given the generic nature of the equestrian image on the coin, and the eyewitness account of the destruction of the horse given by Sabba di Castiglione. Cf. Philip Grierson, "Ercole d'Este and Leonardo da Vincis Equestrian Statue of Francesco Sforza," Italian Studies 14 (1959): 40-8.

41. Luigi Napoleone Cittadella, Notizie relative a Ferrara, I, Ferrara, 1864, p. 428.

42. For a history of the Napoleon monument, fragments of which still survive in the Casa Romei, see Lino Sighinolfi, "Il monumento a Napoleone Bonaparte in Ferrara," Atti e memorie della Deputazione di storia patria per l'Emilia e Romagna. Sezione di Ferrara, n.s., 14 (1955): 155-61.

\section{About the author}

Charles Rosenberg received his doctorate in Art History from the University of Michigan in 1974, writing his thesis on the patronage of Borso d'Este, the first Duke of Ferrara. After teaching for a number of years in upstate New York, Rosenberg joined the faculty of Department of Art History of the University of Notre Dame. He has published extensively on matters Ferrarese, including his most recent book, The Este Monuments and Urban Development in Renaissance Ferrara, Cambridge University Press, 1998. He continues to work on the art of Renaissance Ferrara, and is also editing a collection of essays on art and patronage in the courts and citys of Northern Italy in the Renaissance. 